University of Nebraska - Lincoln

DigitalCommons@University of Nebraska - Lincoln

1969

\title{
Managerial Analysis of Doctoral Candidates and Professors: Research Attitudes and Interpersonal Relations
}

Fred Luthans

Richard M. Hodgetts

Follow this and additional works at: https://digitalcommons.unl.edu/managementfacpub

Part of the Business Administration, Management, and Operations Commons, Management Sciences and Quantitative Methods Commons, and the Strategic Management Policy Commons

This Article is brought to you for free and open access by the Management Department at DigitalCommons@University of Nebraska - Lincoln. It has been accepted for inclusion in Management Department Faculty Publications by an authorized administrator of DigitalCommons@University of Nebraska - Lincoln. 


\title{
Managerial Analysis of Doctoral Candidates and Professors. Research Attitudes and Interpersonal Relations
}

\author{
FRED LUTHANS and \\ RICHARD M. HODGETTS \\ University of Nebraska
}

The authors feel that managerial analysis can contribute to the better understanding of many problems facing the modern university. This study, in analyzing the staffing problems of colleges of business administration, utilizes the research attitudes and interpersonal relations between doctoral candidates and their professors.

The body of management knowledge is usually associated with business organizations. However, many other types of organizations in modern society have utilized management knowledge to solve their problems. Government organizations, hospitals, and the military draw from and add to the general body of management knowledge. For example, Dwight Waldo, a scholar of public administration, states:

Business administration and public administration grew up as allied disciplines, and their mutual borrowings, especially those of public administration from business administration, have been large. The inspiring drive of many of the Founding Fathers of public administration was the drive to apply business methods to government. ${ }^{1}$

In the introduction to Modern Concepts of Hospital Administration the editor, J. K. Owen, writes that the book ". . . interprets the field of hospital

'Dwight Waldo, The Study of Public Administration (Garden City, New York: Doubleday, 1955), p. 56 . 
administration in the light of present-day management principles,"2 and Morris Janowitz in his analysis of the professional soldier comments that ". . . in order to accomplish his duties, the military commander must become interested and more skilled in techniques of organization, in the management of morale and negotiation."

Can today's large universities make a similar claim? The typical university is not a band of scholars teaching a few hundred students but has evolved into the multiversity. An example is the huge State University of New York which has grown from 47,634 students in 1960 to about 150,000 today and is forecasted to reach almost 300,000 within the next several years. The New York system is the largest in the country, but all the 100 plus universities with over 10,000 enrollment are experiencing similar growth patterns. Can these universities be managed as they have been for the past two or three generations? The answer is obvious, but yet there presently exists no consistent body of knowledge. Universities must bring their managerial analysis, theory, and techniques up to date just as every other growing institution in our society has done. For instance, James A. Perkins commented, ". . . it is a fact that the university as a social institution has received far less attention than business and government organizations." 4 Thomas R. McConnell in a paper on needed research in universities described the situation in stronger terms when he said, "So little research has been done on how colleges and universities are organized and administered that it is fair to say, in fact, that the field has not been touched." 5 The university does indeed seem to be a fertile area for managerial research.

Of the multitude of problems facing the university, one of the most serious is the student explosion. Some areas of study have been and will be harder hit than others. The colleges of business administration are among those having particularly sharp increases in enrollment. In 1961 , there were about 63,000 total degrees given in business administration. By 1965 this had climbed to $80,000 .{ }^{6}$ Most forecasts indicate a relative gain by colleges of business over most of the other disciplines. A survey by the American Council on Education estimates that 11.5 per cent of the class of 1970 will major in business compared to 7.2 in engineering, 5.8 in English and 4.3 in biology. ${ }^{7}$

2J. K. Owen (ed.), Modern Concepts of Hospital Administration (Philadelphia: W. B. Saunders, 1962), p. 5. 9-10.

${ }^{3}$ Morris Janowitz, The Professional Soldier (London: Collier-Macmillan, 1960), pp.

'James A. Perkins, "The Campus-Forgotten Field of Study," Public Administration Review, XX, No. 1 (Winter, 1960), 1.

'T. R. McConnell, "Needed Research in College and University Organization and Administration," The Study of Academic Administration, ed. Terry F. Lunsford (Boulder, Colorado: Western Interstate Commission for Higher Education, 1963), p. 113.

'A Fact Book on Higher Education, Third Issue (Washington: American Council on Education, 1967), p. 148.

"The Most Frenzied Year in History," Business Week, April 8, 1967, pp. 54-58. 
What implications does this student explosion have for colleges such as business administration? The most immediate problem is for more staffing. The shortage so far has been largely met by employing master degree and all but dissertation (A.B.D.) instructors and assistant professors. However, the strict requirements of accrediting associations, such as the American Association of Collegiate Schools of Business, and the desire to improve their image and quality have forced most colleges to demand their staffs have the terminal degree.

The potential doctorate degree holder thus becomes the key element to the future of business colleges. If these colleges expect to be staffed with professors holding terminal degrees, then logically more analysis and research must be devoted to the doctoral candidate himself. Although every professor in academia has normative solutions and "armchair" theories concerning doctoral candidates, very little analysis or empirical research has been done. For instance, the introduction to one of the very few empirical studies on doctoral students states that "virtually nothing is known about the nonfinancial factors associated with attrition among graduate students." 8 On the other hand, much research has been done on the key personnel of other types of organizations. Attitudinal research and interpersonal relationships, e.g., on superiors-subordinates in industry, are two approaches used by managerial analysis that come quickly to mind. Why not use these same approaches in the analysis of doctoral candidates in our universities? Would not such a study make a contribution to a body of knowledge which hopefully could help solve the major staffing problems facing our universities today and in the future? This exploratory study attempts to use managerial analysis to better understand two important areas: the research attitudes and interpersonal relations of doctoral candidates and their professors.

\section{THE RESEARCH METHOD}

A confidential questionnaire survey was made of a systematic sample of professors and doctoral candidates drawn from the 43 universities which offer doctor's degrees (Ph.D. or D.B.A.) in business administration. ${ }^{9}$ Questionnaires were sent to three systematically selected department chairmen in each business college. If the department chairman was not a full professor or if there were less than three departments in any college, then a systematically chosen full professor was included in the sample. All economics departments and professors were excluded because many of the business colleges did not include this discipline. The professors were

sJoseph D. Mooney, "Attrition Among Ph.D. Candidates: An Analysis of a Cohort of Recent Woodrow Wilson Fellows," The Journal of Human Resources, III, No. 1 (Winter 1968), 48.

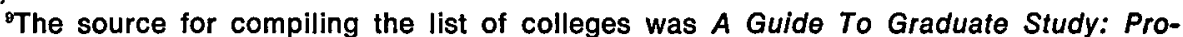
grams Leading to the Ph.D. Degree, 3rd. ed. (Washington: American Council on Education, 1965). 
asked to fill out the confidential questionnaire and include the names of a cross-section of three of their present doctoral candidates. A confidential questionnaire was then sent to each of the doctoral students. Of the 126 faculty members surveyed, a 70 per cent usable response was obtained. Of the 110 candidates asked to fill out a confidential questionnaire, 86 per cent responded, with 81 per cent usable for tabulation purposes.

\section{RESEARCH ATTITUDES}

Research leading to publication and the doctoral dissertation are two areas commonly associated with academic research. These two areas of analysis (publications and the dissertation) were utilized to determine the research attitudes of professors and doctoral students.

\section{Professors' Attitudes Toward Research}

Over half the full professors (department chairmen) felt that teaching graduate students was their primary function. From their viewpoint, teaching undergraduates and academic administration also play a larger role than research for publication. Yet, they have a relatively good publication record. About one in five has published between one to three articles and monographs, while the remainder have published four or more. About three-fourths of those surveyed have also published one or more books. Although research is viewed as a secondary role to teaching, a majority of the professors felt that research for publication is absolutely necessary to keep up in one's field and a professional obligation. Only three professors (4 per cent) felt that research for publication was a necessary evil required for advancement.

The professors in the sample have a wealth of experience on dissertation research. About one-third have served on from 1 to 10 doctoral committees, another third on from 11 to 20 , and the final third on over 20 doctoral committees. Most have been chairman of several committees and are currently the head of from one to five doctoral committees. Most of the professors responded that the purpose of the dissertation was to teach the student how to conduct a research study. Closely related, and ranked next in importance, was teaching the student how to translate raw data into a readable product and then make a contribution to basic knowledge in the field. Almost all agree that the dissertation should not be eliminated, and the professors expressed a fair degree of enthusiasm over current dissertation research topics.

\section{Doctoral Candidates' Attitudes Toward Research}

About half of the doctoral students in the sample are under $\mathbf{3 0}$ years of age. A large majority are married ( 82 per cent) and have a family (twothirds of those married have children). All those responding indicated 
they had teaching experience, and most had some type of business experience.

The analysis of the candidates' attitudes toward research is based largely on the doctoral dissertation. Almost one-third of the respondents had been working on their dissertations less than six months, another third from six months to a year, and the remaining third for over a year. Most of the graduate students indicated they were having some degree of difficulty with their dissertations (see Table 1). Choosing an appropriate topic seemed to be the biggest problem. About two-thirds of the candidates responded that they alone chose their topic, and the other one-third said that they selected it in conjunction with their chairmen. Only two candidates indicated that the chairmen chose their topics for them. Once the topic is chosen, the candidates seem very enthusiastic about it. No one indicated he was unexcited about his topic.

TABLE 1

Doctoral Candidates' Attitudes Toward The Dissertation

\begin{tabular}{|c|c|c|c|c|c|c|}
\hline \multirow{3}{*}{$\begin{array}{c}\text { SPECIFIC AREAS } \\
\cdot\end{array}$} & \multicolumn{6}{|c|}{ DEGREE OF DIFFICULTY } \\
\hline & \multicolumn{2}{|c|}{$\begin{array}{l}\text { Little or } \\
\text { None }\end{array}$} & \multicolumn{2}{|c|}{$\begin{array}{c}\text { Some } \\
\text { Difficulty }\end{array}$} & \multicolumn{2}{|c|}{$\begin{array}{l}\text { Very } \\
\text { Much }\end{array}$} \\
\hline & No. & $\%$ & No. & $\%$ & No. & $\%$ \\
\hline \multirow{4}{*}{$\begin{array}{l}\text { The Dissertation in General } \\
\text { Choosing a Topic } \\
\text { Writing Style } \\
\text { Research Design and/or } \\
\text { Statistics } \\
\text { Building a Rapport with the } \\
\text { Chairman } \\
\text { Keeping All Members of the } \\
\text { Committee Satisfied }\end{array}$} & $\begin{array}{r}6 \\
20 \\
36\end{array}$ & $\begin{array}{r}8 \\
27 \\
50\end{array}$ & $\begin{array}{l}49 \\
28 \\
35\end{array}$ & $\begin{array}{l}69 \\
38 \\
49\end{array}$ & $\begin{array}{c}16 \\
26 \\
1\end{array}$ & $\begin{array}{r}23 \\
35 \\
1\end{array}$ \\
\hline & 10 & 14 & 42 & 61 & 17 & 25 \\
\hline & 56 & 77 & 13 & 18 & 4 & 5 \\
\hline & 28 & 40 & 32 & 46 & 10 & 14 \\
\hline
\end{tabular}

Table 1 also shows that doctoral students are experiencing some problems with their writing styles and research design and statistical methods. A supplementary open-end question asking the students to list their weak points substantiated this finding. Writing ability and research techniques, such as statistical and mathematical methods of analysis, were mentioned more frequently than any other of their admitted weak points.

Even with these expressed difficulties, the doctoral candidate still feels the dissertation is a valuable part of his graduate training. Most of the students indicated that the primary purpose of the dissertation was to teach him how to conduct a research study with secondary aims of teaching how to translate raw data into a readable product and contribute to basic knowledge in the field. Only six students (9 per cent) felt that the dissertation was a mere formality that should be eliminated.

In terms of the candidates' future attitudes toward research for publication, it was found that a majority (60 per cent) felt that it was absolutely necessary to keep up in one's field and a professional obligation. Almost 
a third thought research for publication should be of secondary importance to teaching and service, but only ten per cent had the attitude that it was a necessary evil that will be required for advancement. Furthermore, practically all the respondents indicated that they plan to do teaching and research after receiving their doctorate, rather than concentrating only on teaching or on research.

\section{INTERPERSONAL RELATIONS}

A completely neglected but seemingly vital area of analysis and understanding of doctoral candidates would be their relations with the dissertation chairmen. This candidate-chairman relationship may, in fact, be the most important single determinant of completing the dissertation and thus graduating; it may also affect the graduate's future performance and attitudes toward research. With this assumption in mind, the study tried to gain some insights into the interpersonal relations between candidates and professors from the descriptive data obtained from the confidential questionnaire responses.

\section{Professors' Relations With Their Doctoral Chairmen}

A little over three-fourths of the professors stated that they recalled their own overall graduate training with positive (as opposed to neutral or negative) feelings. When asked how they specifically remembered their doctoral chairmen, the response was about the same. Most (72 per cent) felt their chairmen were very good, some (22 per cent) that they were about average, and only a very few (6 per cent) remembered them as poor.

In interpreting these data, it must be remembered that the professor sample consists of successful scholars. Most are departmental chairmen, and all are full professors. Therefore, the highly positive response toward their graduate training and particularly their doctoral chairmen is in accord with the assumption that the relationship between candidate and chairman may be an important factor in future performance. Furthermore, it is interesting to note the publication record and attitude toward research of those who said they had very good (as opposed to average or poor) doctoral chairmen. About three-fourths of those professors who said they had very good chairmen also had outstanding publication records (four or more articles and one or more books). Two-thirds of those reporting very good chairmen replied that research for publication was absolutely necessary to keep up in one's field and a professional obligation. This finding would tend to reinforce the assumption that relations with doctoral chairmen influence future attitudes toward research. There were so few negative replies that no meaningful analysis could be made of those stating they had poor graduate training and doctoral chairmen. However, it is interesting to note that those few who felt their chairmen were poor 
mainly remembered their lack of knowledge and research techniques. The great majority of professors who felt they had very good chairmen primarily remembered the realistic standards and secondarily, in order, the warmth, concern, knowledge, and research techniques of their doctoral chairmen.

\section{Relations Between Current Candidates And Their Professors}

Table 1 showed that in regard to various aspects of the candidate's dissertation, building a rapport with his chairman presented the least amount of difficulty. The doctoral students have a very high opinion of their chairmen. When asked the confidential question, "All things considered, how would you rate your chairman on the five-point continuum below?" 45 per cent answered excellent, 36 per cent good, 16 per cent average, with only 3 per cent fair, and 1 per cent poor. Therefore, at first glance practically all the graduate students surveyed seem to have a good relationship with their chairmen and think they are doing an excellent job.

Cross analysis of professors' and candidates' responses to the same questions supported this positive relationship. With regard to the amount of control professors exercise over their doctoral students, the two groups seemed in agreement. Both professors and students perceive a fair degree of control exercised by the chairmen over their candidates. Table 2 shows more specific areas of interpersonal relations. Students and professors are remarkably close in their evaluations of their relationships. Both students and professors are pretty well satisfied with each other concerning various requirements of the dissertation and keeping the student encouraged and well informed. In fact, the study found a large majority of professors (81 per cent) and candidates (72 per cent) would like to maintain their present relationship. A minority of professors (18 per cent) and students (25 per cent) desired a closer relationship, but only a couple of each group wanted a less close relationship.

Subjective answers also supported the generally positive relationship between candidates and professors. The open-ended questions were designed to supplement how the two groups felt about themselves and about each other. The professors were asked what they felt the candidates liked least and most about their dissertation chairmen. The candidates were then asked the same question. The professors indicated that, from the viewpoint of the student, their major asset was their helpfulness. Inaccessibility to the student was listed as their major drawback. The candidates gave varied answers but generally agreed that helpfulness was the biggest plus, and inaccessibility was the major fault of their chairmen. Other drawbacks were mentioned but not generally supported by the other group. For example, the professors felt that, in the eyes of the candidate, 
their standards were too high, and the candidates sometimes stated that their chairmen were vague, inconsistent, and authoritarian.

TABLE 2

Interpersonal Relations Between Doctoral Candidates and Dissertation Chairmen

\begin{tabular}{|c|c|c|c|c|c|c|}
\hline \multirow{3}{*}{ TYPES OF INTERACTION } & \multicolumn{6}{|c|}{ EVALUATION OF THE RELATIONS } \\
\hline & \multicolumn{2}{|c|}{ Poor } & \multicolumn{2}{|c|}{$\begin{array}{l}\text { Average } \\
\text { or } \\
\text { Normal }\end{array}$} & \multicolumn{2}{|c|}{ Good } \\
\hline & $\begin{array}{l}\text { \% of } \\
\text { Pro- } \\
\text { fessors }\end{array}$ & $\begin{array}{l}\text { \% of } \\
\text { Pro- } \\
\text { tessors }\end{array}$ & $\begin{array}{c}\% \text { of } \\
\text { Pro- } \\
\text { fessors }\end{array}$ & $\begin{array}{l}\% \text { of } \\
\text { Can- } \\
\text { didates }\end{array}$ & $\begin{array}{c}\% \text { of } \\
\text { Can- } \\
\text { didates }\end{array}$ & $\begin{array}{l}\% \text { of } \\
\text { Can- } \\
\text { didates }\end{array}$ \\
\hline $\begin{array}{l}\text { Communicating in the } \\
\text { Areas of: } \\
\text { Initial or Expanded } \\
\text { Research } \\
\text { Grammar and Format }\end{array}$ & $\begin{array}{r}7 \\
14\end{array}$ & $\begin{array}{r}9 \\
11\end{array}$ & $\begin{array}{l}63 \\
41\end{array}$ & $\begin{array}{l}40 \\
39\end{array}$ & $\begin{array}{l}30 \\
45\end{array}$ & $\begin{array}{l}51 \\
50\end{array}$ \\
\hline $\begin{array}{l}\text { Encouragement for } \\
\text { the Student } \\
\text { Keeping Abreast of How }\end{array}$ & 1 & 16 & 39 & 31 & 60 & 53 \\
\hline $\begin{array}{l}\text { Keeping Abreast of How } \\
\text { the Student is } \\
\text { Progressing } \\
\text { Keeping the Student } \\
\text { Informed on How the } \\
\text { Chairman Thinks the } \\
\text { Candidate is Progressing }\end{array}$ & 6 & 12 & 44 & 50 & 48 & 38 \\
\hline
\end{tabular}

The open-ended questions also requested both professors and candidates to list the strong and weak points of the candidates. Motivation, knowledge and breadth of background, and intelligence were listed, in order, by the professors as the strongest points. Over half the professors surveyed mentioned writing and research ability as the greatest weakness of doctoral students. This weak point of candidates was one of the few minor disagreements between professors and candidates. Many of the candidates (almost half) felt that writing and research ability was their strongest attribute, with motivation being second. In listing their weak points, they presented a widely varied list. Writing and research ability was mentioned more than any other single weakness (about one out of every four), but a far greater number (one out of every two) listed it as their major strength. Both groups generally agreed that statistics, mathematics, and economic theory were specific weak areas for the business doctoral student.

A final area of analysis was concerned with the graduate student's relations with the other members of his doctoral committee. The students' responses indicate that this relationship is also relatively good. Most doctoral candidates interact with committee members during the research design (65 per cent) and after the first draft (76 per cent) phases of the dissertation. However, in a great majority of the cases (78 per cent) the student perceives his chairman as having the most power and influence in his committee. Nevertheless, Table 1 showed that the candidate is not 
experiencing much difficulty in his relationship with other committee members.

\section{SUMMARY AND CONCLUSIONS}

The overall analysis suggests that business administration doctoral candidates and their professors have a positive attitude toward research for publication and the doctoral dissertation. Most of the professors and graduate students felt that research for publication was absolutely necessary and a professional obligation. The doctoral students did indicate they were having some degree of difficulty with their dissertations. This difficulty was especially brought out in the beginning phase of choosing an appropriate topic. However, once the topic is decided upon, the students and professors seem very enthusiastic about the chosen subject. Almost all the candidates and professors agreed that the dissertation is necessary to teach the student how to conduct a research study and should not be done away with.

In the area of interpersonal relations, it was found that the present full professors recalled having good relationships with their own doctoral chairmen and that the current relationship between doctoral candidates and their professors is mutually satisfactory. Although inconclusive because the professor sample contained all relatively successful scholars, the analysis does suggest that professors who had a good relationship with their doctoral chairmen currently have a good publication record and attitude toward research. This finding should stress the importance of maintaining a good relationship between chairman and candidate. Generally, both the candidates and professors feel this good relationship presently exists and they would not like to change it.

Some current discussions inferring that the academic community and graduate students see no purpose in the dissertation and would like to eliminate it and that candidates have a poor working relationship with their doctoral chairmen were found to be untrue in this study. It is hoped that these and other misconceptions have been clarified and that there is now a better understanding of the research attitudes and interpersonal relations of doctoral students and their professors. This improved understanding of these two areas is only the beginning. More research is needed to fully understand the doctoral candidate and his problems if today's universities expect to meet the staffing shortages created by the exploding student population. Management scholars could logically contribute to this understanding. The authors hope this study demonstrated the usefulness of managerial analysis. There seems to be a crying need for management professors to make introspective analyses of heretofore unthought of or out of bounds areas in their own organizations-the modern universities. 